\title{
PRODUCTIVE EFFICIENCY OF PRIMIPAROUS ABERDEEN ANGUS COWS OF THE DIFFERENT BODY SIZES AND MILK PRODUCTION LEVELS
}

\author{
EFICIENCIA PRODUTIVA DE VACAS PRIMÍPARAS ABERDEEN ANGUS DE \\ DIFERENTES TAMANHOS CORPORAIS E NÍVEIS DE PRODUÇÃO DE LEITE
}

\author{
Ricardo Zambarda VAZ ${ }^{1}$; Edson Luis de Azambuja RIBEIRO ${ }^{2}$ João RESTLE ${ }^{3}$; \\ Fabiano Nunes VAZ ${ }^{4}$; Paulo Santana PACHECO ${ }^{5}$; José Luiz MOLETTA ${ }^{6}$ \\ 1. Teacher, Doctor at the Federal University of Pelotas, Department of Animal cSience, Pelotas, RS, Brazil; ${ }^{2}$ Teacher, Doctor at the \\ State University of Londrina, Department of Animal Science, Londrina, PR, Brazil; ${ }^{3 .}$ Teacher, PhD at the Federal University of Goiás, , \\ Goiânia, GO, Brazil; ' Teacher, Doctor at the Federal University of Santa Maria, Department of Agricultural Education and Rural \\ Extension, Santa Maria, RS, Brazil; ${ }^{5 \cdot}$ Teacher, Doctor at the Federal University of Santa Maria, Department of Animal Science, Santa \\ Maria, RS, Brazil; ${ }^{6}$ Researcher, IAPAR - Agronomic Institute of Paraná, Ponta Grossa, PR, Brazil.
}

\begin{abstract}
Assessment of the productive efficiency of 30 primiparous Aberdeen Angus cows of different body sizes, classified at calving as heavy $(375 \pm 10.5 \mathrm{~kg})$ or light $(283 \pm 7.7 \mathrm{~kg})$, and different total milk-yield levels, classified as high $(868 \pm 24.5 \mathrm{~kg})$ or low $(547 \pm 18.3 \mathrm{~kg})$. Heavy cows were superior in weight at calving and weaning, but there were no differences in milk yield and weight at birth and weaning of calves. Heavy cows were less efficient than light cows in the production of kilograms of calves per $100 \mathrm{~kg}$ of cows at calving and at weaning. High milk producing cows were heavier at calving and had heavier calves at birth and weaning, but did not differ between the milk-yield levels for the variation in daily weight. The variation in daily weight of the calves was greater from high-producing cows. High milk producing dairy beef cows were more efficient at weaning, and their calves required less milk to produce one kilogram of live weight.
\end{abstract}

KEYWORDS: Body condition. Calving. Lactation persistency. Weaning.

\section{INTRODUCTION}

The intensification and competitiveness of beef cattle farming lead producers to seek moreefficient animals adapted to the productive systems, with greater production in less time and at lower costs, thereby providing better economic indices to the activity. Despite the advance in technologies and their use, native grasslands remain the basic food for beef cattle, and, because of the climatic conditions and diversity of species in southern Brazil their quantity and quality oscillate throughout the production cycles; moreover, the poor management to which they are subjected (ROSA et al., 2012) limits animal production in certain periods.

To increase productivity indices, productive systems usually associate better feeding conditions to the nutritional requirements of the categories. However, in extensive conditions in the subtropics used in southern Brazil the nutrient availability does not meet the requirements of animals, resulting in low productive indices, which impacts production. In the South of Brazil, approximately two cows are required to wean one calf per year (VAZ et al., 2010a).

The best indicator for evaluating beef-cattle breeding herds under extensive conditions is the weaning rate (VAZ et al., 2010b). However, the percentage of calves in relation to the number of cows alone is not a consistent datum, since the quantity must be associated with the quality of production. Therefore, the weight of calves at weaning and the kilogram of calves per cow kept in the herd are efficient indicators for the evaluation and decision-making process of production systems.

The diversity of animal production leads us to believe in the existence of animals better adapted to the environment (VAZ et al., 2010b) that outdo the other individuals due to a likely better genetic capacity to produce in the conditions to which they are exposed (DEESE; KOGER, 1967). In this regard, an increase in productivity involves the use of adapted animals, aiming to provide breeding herds with increased production at weaning, which will ultimately reflect in a younger slaughter age for males (RESTLE et al., 2004), and younger age at puberty and at the first reproductive performance of females (VAZ; LOBATO 2010a). The present study aimed to evaluate the productive performance from calving to weaning of primiparous Aberdeen Angus beef cows with two body sizes and two milk yields under extensive rearing conditions, as depending on body size and milk production of inhibitors of the production efficiency of the herds. 


\section{MATERIAL AND METHODS}

The experiment was carried out in the facilities of the Animal Science Department of the Federal University of Santa Maria, located in the physiographic region Central Depression of Rio Grande do Sul State, Brazil (95 m altitude, 29²43' S latitude, $53^{\circ} 42^{\prime} \mathrm{W}$ longitude). The climate of the region is a $\mathrm{Cfa}$ (subtropical humid) type, according to the Köppen classification (MORENO, 1961).

This trial utilized thirty primiparous Aberdeen Angus cows primiparous at three years of age, with an average body condition score of 3.0 on a scale of 1 to 5 (JAUME; MORAES, 2002), calved in the spring during the months of September and October, and classified at calving, according to their body weight, as "heavy" (average weight of $375 \mathrm{~kg}$, ranging from 320 to $380 \mathrm{~kg}$ ) and "light" (average weight of $283 \mathrm{~kg}$, ranging from 220 to $314 \mathrm{~kg}$ ).

The cows were from the same herd and born in the same spring calving season during September and October. Cows from the two weight groups were managed as single group from birth on until they weaned their first calves. They were maintained exclusively on native pasture with the exception of their first and second winter when heifers were maintained grazing on oats (Avena strigosa) plus ryegrass (Lolium Mutiflorum) pasture. Weight differences are mainly due to their individual genetics and environmental factors during their growth like their mother's milk production, which was not measured.

Animals were managed in a single lot on a native pasture with stocking rate of $405 \mathrm{~kg}$ body weight per hectare. To evaluate the efficiency of the herds, cows and calves were weighed at calving and weaning (at 235 days, on average), and also additionally at every 28 days to control the stocking rate, maintaining the same with continuous grazing and fixed load 0,9 U.A./ha. The weight gained between calving and weaning was determined as the difference between the weights divided by the evaluation period.

The botanical composition of native pastures of the region is diverse and can present composite intermingled grasses. The predominant species of grasses are Paspalum notatum in the highest parts, Axonopus fissifolius in wetter parts, and mainly the Andropogon lateralis as superior extract. Among the legumes are some clovers but with great emphasis on the family Desmoduim.

To estimate the milk yield of the cows, the direct method was adopted, by collecting milk from two udder quarters (one rear and one front). The amount collected was multiplied by two to obtain the total production from the udder and corrected for production in the $24 \mathrm{~h}$, determined by the interval between suckling and milking. For this purpose, the calves were separated from their mothers at $11 \mathrm{~h} 00$ and put to suckle at $18 \mathrm{~h} 30$, lasting 30 minutes. Afterwards, they were again separated, remaining separated in the corral until the morning of the following day, whereas the cows were released in paddocks provided with native pasture and water. On the following day, at $06 \mathrm{~h} 00$, after being restrained in an appropriate chute for the practice, a dose of $30 \mathrm{IU}$ of oxytocin/cow was applied to facilitate the milk release. Subsequently, the udder was washed and disinfected and cows were manually milked.

Observations to determine milk yield followed the weighting dates. Milk yield, in the periods, was estimated by the following formula: $M Y_{n}=\left[\left(M_{n}+M_{n-1}\right) / 2\right] \times 28$, where $M Y_{n}$ is milk yield in the period of 28 days; $M_{n}$ is the milk yield estimated on the day, i.e., the production observed on the weighting day multiplied by two; and $n=14$; $24 ; 60 ; . . ., 235$ days (ALENCAR et al., 1996). The total milk yield of each cow was estimated by adding all $\mathrm{MY}_{\mathrm{n}},\left(\mathrm{TMY}=\sum \mathrm{MY}_{\mathrm{n}}\right)$. According to the total milk yields, the cows were divided into two classes: high-producing cows (average $868 \mathrm{~kg}$, ranging from 700 to $1211 \mathrm{~kg}$ ) and low-producing cows (average $537 \mathrm{~kg}$, varying from 326 to $686 \mathrm{~kg}$ ). Lactation persistency was calculated as the ratio of the difference between the last daily production and the highest production found in the period, in days. This variable is expressed in g/day and represents how much milk yield decreases per day after the peak of lactation (JENKINS et al., 2000).

For productivity and efficiency, the total weight gains of cows and calves $(\mathrm{kg}$ ) from calving to weaning were considered. The productive efficiencies of the cows of different sizes at calving (PEC) and weaning (PEW) were evaluated according to the methodology described by RIBEIRO et al. (2001). The estimates were considered in relation to the amount $(\mathrm{kg})$ of calves weaned for every $100 \mathrm{~kg}$ of cows calved: PEC = $\left(\mathrm{C}_{\mathrm{a}} \mathrm{WW} / \mathrm{C}_{\mathrm{o}} \mathrm{WC}\right) * 100$; and for every $100 \mathrm{~kg}$ of cow with weaned calf: PEW $=\left(\mathrm{C}_{\mathrm{a}} \mathrm{WW} / \mathrm{C}_{\mathrm{o}} \mathrm{WW}\right) * 100$, where $\mathrm{C}_{\mathrm{a}} \mathrm{WW}$ is the calf weight at weaning, at 235 days of age.

The experimental design was completely randomized, in a $2 \times 2$ factorial arrangement (two body-weight groups $\times$ two milk-yield categories), and results were subjected to analysis of variance and the F test. Effects of animal size (heavy and light cows), milk-yield level (high and low), and animal size $\times$ milk yield interaction, adjusted by 
age, sex, and genetic group of the calves (pure Angus or Nellore crossbred) were used in the mathematical model employed in the analyses. Analyses were carried out adopting 5\% as the significance level. Means were compared by the " $t$ " test. The variable percentage of pregnancy was analyzed by the chi-squared test at $5 \%$ significance level.

\section{RESULTS AND DISCUSSION}

As there was no significant interaction ( $P>0.05)$, the results for body size and milk-yield level are presented and discussed separately. The classification of groups according to cow weight determined differences in cow body weight at calving $(\mathrm{P}<0.05)$, which remained until the weaning of calves, not affecting calves weights at birth and weaning (Table 1).

Heavier cows produce calves with higher pre-weaning growth rates and consequently heavier at weaning (MERCADANTE et al., 2003). However, when the environmental and nutritional adversity post-calving are limiting, their high maintenance costs may compromise milk production and the performance of calves
(CERDÓTES et al., 2004), or, in the case of the present study, this may be due to the fact that they are primiparous and still growing, with a greater nutritional requirement when compared with adult cows (VAZ et al., 2010a). Heavier animals are important, because the revenues from beef-cattle breeding herds are a function of the sale of the kilograms of body weight, but most yields and productive performances should be compatible, and not be affected by the larger size of the animals.

Both the cows from the light group and the heavy ones had negative variations $(\mathrm{P}>0.05)$ in body weight during the lactation period. These body weight losses by the cows are due to the greater requirement of the cow-calf set during lactation, which can increase by $85-90 \%$ at third month up to 100 to $120 \%$ by the fifth month of lactation (ROVIRA, 1996). The similar performance of cows of different sizes may be related to the nutritional level of the diet, or the cows may also compensate for the greater maintenance requirement by a greater utilization of the body reserves (MERCADANTE et al., 2003), which might limit their future reproductive performance (CERDÓTES et al., 2004).

Table 1. Means and standard errors for development, performance, and productive-efficiency characteristics of primiparous Aberdeen Angus cows with different body sizes and their calves

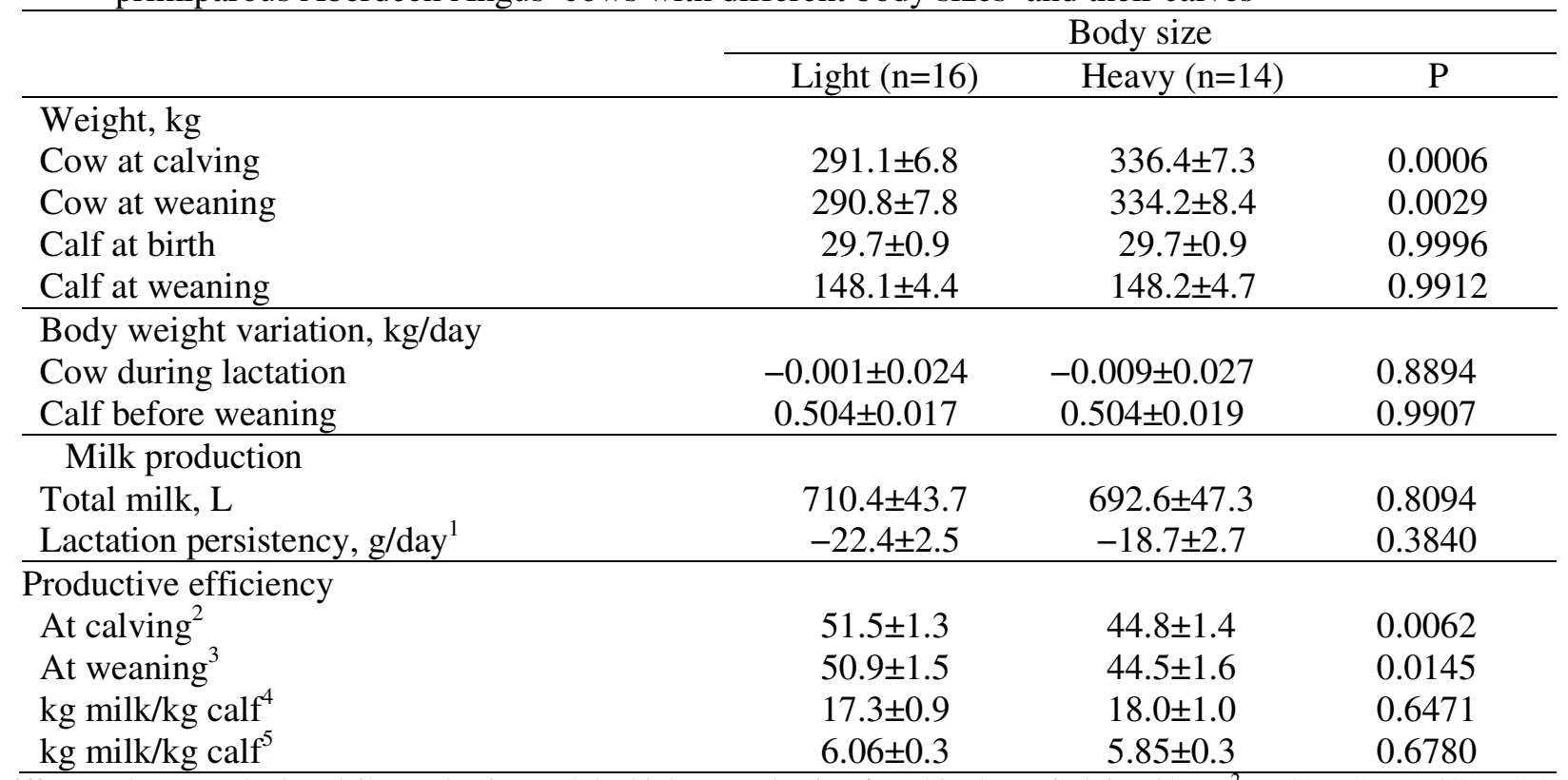

${ }^{1}$ Difference between the last daily production and the highest production found in the period, in $\mathrm{g} /$ days $;{ }^{2} \mathrm{PEC}=(\mathrm{CaWW} / \mathrm{CoWC}) * 100$; relation of the amount $(\mathrm{kg})$ of calves weaned for every $100 \mathrm{~kg}$ of cows calved; ${ }^{3} \mathrm{PEW}=(\mathrm{CaWW} / \mathrm{CoWW}) * 100$; relation of the amount $(\mathrm{kg})$ of calves weaned for every $100 \mathrm{~kg}$ of cows weaned; ${ }^{4}$ Total milk production divided by calf weight gain $=\mathrm{kg}$ of milk to produce 1 $\mathrm{kg}$ of calf; ${ }^{5}$ Percentage efficiency of milk production.

This performance is often explained by the order of priority in the partition of nutrients, because lactation is an exhausting activity, in which cows tend to produce more milk at the expense of body weight. Calegare et al. (2009) found positive correlations between the increase in cow size and 
the efficiency of the calf in the pre-weaning stage; however, analyzing the efficiency of the cow/calf pair, correlations were negative.

Lighter cows were more efficient in calf production at calving and at weaning, as compared to heavier cows, by 14.96 and $14.38 \%$, respectively. Better results for smaller cows indicate that the outcomes are associated with the compatible performances of the calves that displayed better productivity (EUCLIDES FILHO et al., 1995; RIBEIRO et al., 2001). Animals with a smaller body size typically have greater production in kilogram of weight of calves in relation to weight of cows, both at calving and at weaning (VAZ et al., 2010b). Despite the lack of differences in the weights at birth and weaning of calves and in the variations of body weight of cows during lactation of light and heavy cows (Table 1), the productive efficiencies were favorable for the lighter animals with greater calf weight-to-cow weight ratios, indicating that the maintenance cost for the cow-calf productive system is expensive (RIBERO et al., 2001). This demonstrates that the weaning of heavier calves generated from smaller cows is efficient, characterizing lower nutrient intake.

Thus, breeding herds should be evaluated systemically; i.e., not only prioritizing the production of kilograms of calves/cow weight, but the number of cows kept in the system, associating this production to the reproductive performance. Larger sizes should be accompanied by greater sexual precociousness, to minimize the disadvantages of the adult size (CALEGARE et al., 2009). These results demonstrate that cows of smaller size associated with good development of calves are the most efficient in producing kilograms of calves due to their lower nutritional requirement, which, on the average of the two body sizes, is less than $29.80 \%$ of the TDN requirements (NRC, 1996). Smaller animals or animals with lower potential for milk production are more efficient when food resources are limiting (VARGAS et al., 1999). The efficiencies of milk productions expressed in liters of milk per kilogram of weaned calf and this conversion efficiency in percentage values did not differ between light and heavy cows $(\mathrm{P}>0,05)$. The average values of $17.6 \mathrm{~L}$ and $5.95 \%$ demonstrate that the transformation of pasture into milk and of the latter into calf weight is inefficient and wearing for the cow and the productive system.

Cows with higher total milk yields were heavier at calving $(\mathrm{P}<0.05)$ as compared with those with low total milk yields; this difference was diluted throughout the lactation (Table 2).

Table 2. Means and standard errors for development, performance, and productive-efficiency characteristics of primiparous Aberdeen Angus cows with different milk-yield levels and their calves

\begin{tabular}{|c|c|c|c|}
\hline & \multicolumn{3}{|c|}{ Milk yield } \\
\hline & Low $(n=16)$ & High $(n=14)$ & $\mathrm{P}$ \\
\hline \multicolumn{4}{|l|}{ Weight, kg } \\
\hline Cow at calving & $301.3 \pm 6.6$ & $326.2 \pm 6.6$ & 0.0222 \\
\hline Cow at weaning & $308.6 \pm 7.6^{\mathrm{a}}$ & $316.5 \pm 7.6$ & 0.5045 \\
\hline Calf at birth & $27.4 \pm 0.8$ & $31.9 \pm 0.8$ & 0.0021 \\
\hline Calf at weaning & $135.8 \pm 4.3$ & $160.8 \pm 4.3$ & 0.0008 \\
\hline \multicolumn{4}{|l|}{ Body weight variation, $\mathrm{kg} / \mathrm{day}$} \\
\hline Cow during lactation & $0.031 \pm 0.024$ & $-0.041 \pm 0.024$ & 0.0653 \\
\hline Calf before weaning & $0.460 \pm 0.017$ & $0.548 \pm 0.017$ & 0.0027 \\
\hline \multicolumn{4}{|l|}{ Milk yield } \\
\hline Total milk, L & $537.0 \pm 42.7$ & $868.0 \pm 42.7$ & 0.0001 \\
\hline Lactation persistency, g/day ${ }^{1}$ & $-13.8 \pm 2.5$ & $-27.3 \pm 2.5$ & 0.0017 \\
\hline \multicolumn{4}{|l|}{ Productive efficiency } \\
\hline At calving ${ }^{2}$ & $46.2 \pm 1.3$ & $50.8 \pm 1.3$ & 0.0628 \\
\hline At weaning $^{3}$ & $44.6 \pm 1.4$ & $51.8 \pm 1.4$ & 0.0030 \\
\hline $\mathrm{kg}$ milk/kg calf ${ }^{4}$ & $20.6 \pm 0.9$ & $14.7 \pm 0.9$ & 0.0004 \\
\hline $\mathrm{kg}$ milk/kg calf ${ }^{5}$ & $5.06 \pm 0.3$ & $6.87 \pm 0.3$ & 0.0006 \\
\hline
\end{tabular}

${ }^{1}$ Difference between the last daily production and the highest production found in the period, in $\mathrm{g} / \mathrm{days} ;{ }^{2} \mathrm{PEC}=(\mathrm{CaWW} / \mathrm{CoWC}) * 100$; relation to the amount $(\mathrm{kg})$ of calves weaned for every $100 \mathrm{~kg}$ of cows calved; ${ }^{3} \mathrm{PEW}=(\mathrm{CaWW} / \mathrm{CoWW}) * 100$; relation to the amount $(\mathrm{kg})$ of calves weaned for every $100 \mathrm{~kg}$ of cows weaned; ${ }^{4}$ Total milk production divided by calf weight gain $=\mathrm{kg}$ of milk to produce 1 $\mathrm{kg}$ of calf; ${ }^{5}$ Percentage efficiency of milk production.

Light cows at calving tend to have lower milk yields, which is aggravated after certain body weights that become limiting to production. Between the milk-yield groups, the low-producing 
cows were $11.7 \%$ lighter at calving and produced on average $61.3 \%$ less milk. The non-existence of differences in body weight at weaning is a consequence of the milk yield of the higherproducing cows, which probably maintained larger milk production to the detriment of body reserves. Low-producing cows had body weight variations of $0.031 \mathrm{~kg}$, whereas high-producing cows had variations of $-0.041 \mathrm{~kg}(\mathrm{P}<0.065)$ during lactation, demonstrating that the requirements for maintenance and production of larger cows are higher as compared with that of smaller cows.

Calves born from cows with low milk yields were lighter at birth and at weaning as compared with calves born from high-producing cows. The lower weight at birth is probably a result of the lower weight of the cows, which are highly correlated, and also because the smaller size leads to lower intakes and smaller intrauterine space, limiting the growth of the fetuses (MONTIEL; AJUHA, 2005). The weaning weight of the calves behaved according to their performance from birth to weaning, and the latter was correlated with milk yield $0.6161 \quad(\mathrm{P}<0.0003)$, demonstrating the importance of this trait in the production of breeding herds.

Restle et al. (2001) emphasized the importance of milk yield, stating that it cannot be an inhibitory factor for the subsequent reproduction, and that the nutritional management of the herd should consider requirements of beef cows in the different physiological stages (MONTIEL; AJUHA, 2005); these factors are potentiated in extensive systems held on natural pastures, due to nutritional restrictions (VAZ; LOBATO, 2010b). However, Pimentel et al. (2005) found, in Hereford cows reared in extensive conditions, that milk yield was not a limiting factor to post-calving fertility. Nevertheless, despite being insufficient for the change of one point in body condition score, the weight gain post-calving was positively correlated with parturition and calf weight at weaning. Cows with higher milk production commonly wean heavier calves (RESTLE et al., 2004), which reduces the body condition of the cow and the reproductive efficiency of the system (WETTEMANN et al., 2003).

The milk-yield level influenced the lactation persistency $(\mathrm{P}>0.05)$. The daily decrease in milk production of higher-producing cows was $97.8 \%$ higher than that of the other cows, demonstrating that body size and milk production, i.e., factors of greater energy requirements, are determinants of more marked reductions of production as compared with cows of lower nutritional requirements. The nutritional effect on the production, the time of the lactation peak, and the total production of nine breeds were studied by Jenkins and Ferrell (1993), and all variables increased proportionally to the energy intake. The milk production persistency is associated with the total production of the cow and with the value of the peak of lactation, with cows with higher yields having a lower production persistency. Milk production and its persistency can vary as a function of several factors such as nutrition and age of the cow and the consumption capacity of the calf. PIMENTEL et al. (2006) found a reduction in 24.01 vs. $12.23 \mathrm{~g} /$ day, in values when comparing multiparous and primiparous cows with total milk yields during 189 days of 1158 and $915 \mathrm{~L}$, respectively. The milk yield of beef cows can be explained by the production potential and by the capacity of the calf to extract the milk, with productions decreasing if the calves do not consume all the production, leaving residual milk (MENDONÇA et al., 2002).

Cows with lower milk production weaned on average $9.96 \%$ fewer kilograms of calf for every $100 \mathrm{~kg}$ of cow at calving and $16.1 \%$ kilogram of calf for every $100 \mathrm{~kg}$ of cow at weaning in comparison with higher-producing cows. These values demonstrate that milk production is decisive for the development of the calves. The weaning weight of the calves is a reflection of the milk production of the cows, which increases as the weaning age is reduced, because as the calf ages, the dependence on the milk from its mother is also reduced, and crossbreeding can mitigate losses (MURPHY et al., 2008).

Calves born from cows with lower yields were less efficient in the evaluation of the amount of milk required to produce one kilogram of calf weight $(20.6 \mathrm{~kg})$, or, in relative terms, the percentage of transformation of milk into calf body weight $(5.06 \%)$, when compared with higherproducing cows (14.7 $\mathrm{kg}$ and $6.87 \%$, respectively). The better use of milk production can be explained by the likely larger size of the animals from the group, because the cows were heavier at the beginning of the experiment, with heavier calves at calving and at weaning, demonstrating selection for development and consequently greater intake and better performance. This can be verified by the relative efficiency, in which the offspring of higherproducing cows had a greater production efficiency of $6.87 \mathrm{~kg}$ for every $100 \mathrm{~kg}$ of milk consumed as compared with calves born from cows of lower yields, which generated only $5.06 \mathrm{~kg}$ of body weight for every $100 \mathrm{~kg}$ of milk consumed. 
The milk production of cows is fundamental for the development of calves and for the weaning weight (RESTLE et al., 2004). However, greater milk yields are associated with greater depletion of body reserves, or with better nutritional levels (JENKINS; FERREL, 1993). Therefore, animal efficiency should be sought by reducing the requirements of cows; by better utilizing the forage resources; and by choosing adapted animals with lower maintenance costs and greater productivity in relation to their body weight, aiming at greater biological efficiency to the productive systems (RESTLE et al., 2004).

\section{CONCLUSIONS}

With the same body condition, larger Abeerden Angus cows are heavier at calving and weaning than smaller cows; however, the latter are more efficient in producing kilograms of calf at calving and at weaning.

High-milk-yield beef cows are heavier at calving and produce heavier calves at calving and at weaning, although the daily decrease in milk production is greater than that of low-producing cows. Higher-producing cows are more efficient in the production of calves at weaning, requiring less milk per kilogram of calf produced

RESUMO: Objetivou-se avaliar a eficiência produtiva de 30 vacas primíparas Aberdeen Angus, de diferentes tamanhos corporais, classificadas ao parto em pesadas $(375 \pm 10,5 \mathrm{~kg})$ ou leves $(283 \pm 7,7 \mathrm{~kg})$ e diferentes produções totais de leite, classificadas em alta $(868 \pm 24,5 \mathrm{~kg})$ ou baixa produção $(537 \pm 18,3 \mathrm{~kg})$. Vacas pesadas foram superiores no peso ao parto e ao desmame sem diferença na produção de leite e no peso ao nascimento e desmame dos bezerros. Vacas pesadas foram menos eficientes na produção de quilograma de bezerros por $100 \mathrm{~kg}$ de vacas ao parto e ao desmame. Vacas de alta produção de leite foram mais pesadas ao parto, bem como produziram bezerros mais pesados ao nascer e ao desmame, porém não diferiram entre os níveis de produção de leite na variação diária de peso. A variação diária de peso dos bezerros foi superior nos filhos de vacas de altas produções de leite. Vacas de alta produção de leite foram mais eficientes ao desmame e seus bezerros necessitaram de menor quantidade de leite para produzir um quilo de peso vivo.

PALAVRAS-CHAVE: Condição corporal. Desmame. Parto. Persistência da lactação.

\section{REFERENCES}

ALENCAR, M. M.; TULLIO, R. R.; CRUZ, G. M.; OLIVEIRA, M. C. S. Produção de leite da vaca e desenvolvimento do bezerro em gado de corte. Revista Brasileira de Zootecnia, v. 25, p. 92-101, 1996. Available at: http://www.alice.cnptia.embrapa.br/bitstream/doc/42959/1/PROCIMMA1996.00002.pdf. Accessed on Nov. 12, 2014.

CALEGARE, L.; ALENCAR, M. M.; PACKER. I. U.; FERREL, C. L.; LANNA, D. P. D. Cow/calf preweaning efficiency of Nellore and Bos Taurus x Bos indicus crosses. Journal of Animal Science. v. 87, p. 740-747, 2009. Available at:

https://www.animalsciencepublications.org/publications/jas/articles/87/2/0870740?highlight=\&search-result=1. Accessed on Dec. 10, 2014. doi:10.2527/jas.2007-0759

CERDÓTES, L.; RESTLE, J.; BRONDANI, I. L.; SOCCAL, D. C.; FERNANDES, M.S. Desempenho produtivo de vacas de quatro grupos genéticos submetidas a diferentes manejos alimentares, desmamadas aos 42 ou 63 dias de idade. Revista Brasileira de Zootecnia, v. 33, n. 3, p. 585-596, 2004. Available at: http://www.scielo.br/scielo.php?script=sci_arttext\&pid=S1516-35982004000300009\&lng=en\&nrm=isso. Accessed on: Nov. 11, 2014. doi: 10.1590/S1516-35982004000300009

DEESE, R. E; KOGER, M. Heritability of reproduction. In: CUNHA, T. J. et al. Factors affecting calf crop. Gainesville: University of Florida, 1967. p. 232-238.

EUCLIDES FILHO, K.; FIGUEIREDO, R.; EUCLIDES, V. P. B. Eficiência de produção de vacas de corte com diferentes potenciais para produção de leite. Pesquisa Agropecuária Brasileira, v. 30, p. 1003-1007, 1995. 
JAUME, C. M.; MORAES, J. C. F. Importância da condição corporal na eficiência reprodutiva do rebanho de cria. Bagé: EMBRAPA, 2002. v. 43, jul, p. 1-30. (Documentos)

JENKINS, T. G., FERREL, C. L. Conversion efficiency through weaning of nine breeds of cattle. Beef Research Progress Report., n.4 USDA, Clay Center, p. 156-157, 1993

JENKINS, T. G.; FERREL, C. L.; ROBERTS, A. J. Lactation and calf weight traits of mature crossbred cows fed varying daily levels of metabolizable energy. Journal of Animal Science, v. 78, n. 1, p. 7-14, 2000. Available at: https://www.animalsciencepublications.org/publications/jas/pdfs/78/1/7?search-result=1. Accessed on: Dec. 11, 2014.

MENDONÇA, G.; PIMENTEL, M. A.; CARDELLINO, R. A.; OSÓRIO, J. C. S. Produção de leite em primíparas de bovinos Hereford e desenvolvimento ponderal de terneiros cruzas taurinos e zebuínos. Revista Brasileira de Zootecnia, v. 31, p. 467-474, 2002 (Suplemento). Available at: http://www.scielo.br/scielo.php?script=sci_arttext\&pid=S151635982002000200023\&lng=en\&nrm=iso\&tlng=PT. Accessed on Nov. 30, 2014. doi: 10.1590/S151635982002000200023

MERCADANTE, M. E. Z. PACKER, I. U.; RAZOOK, A. G.; CYRILLO, J. N. S. G.; FIGUEIREDO, L. A. Direct and correlated responses to selection for yearling weight on reproductive performance of Nelore cows. Journal Animal Science, v. 81, n. 2, p. 376-384, 2003. Available at:

https://www.animalsciencepublications.org/publications/jas/articles/81/2/0810376?highlight=\&search-result=1. Accessed on: Nov. 22, 2014. doi:/2003.812376x.

MONTIEL, F.; AHUJA, C. Body condition and suckling as factors influencing the duration of postpartum anestrus in cattle: a review. Animal Reproduction Science, v. 85, n. 1, p. 1-26, 2005. Available at: http://www.sciencedirect.com/science/article/pii/S0378432003002276. Accessed on Nov. 23, 2014. doi: 10.1016/j.anireprosci.2003.11.001.

MORENO, J. A. Clima do Rio Grande do Sul. Porto Alegre. Secretaria Agricultura. 1961. 41p.

MURPHY, B. M.; DRENNAN, M. J.; O’MARA, F. P.; MCGEE, M. Performance and feed intake of five beef suckler cow genotypes and pre-weaning growth of their progeny. Irish Journal of Agricultural and Food Research. v. 47, p. 13-25, 2008. Available at: http://www.teagasc.ie/research/journalarchives/vol47no1/ijafr3606.pdf. Accessed on Jan. 12, 2014.

NATIONAL RESEARCH COUNCIL - NRC. Nutrient requeriment of beef cattle. Washington D.C.: National Academy Press, 1996. 244p.

PIMENTEL, M. A.; MORAES, J. C. F.; JAUME, C. M.; LEMES, J. S.; BRAUNER, C. C. Produção de leite e desempenho pós parto de vacas Hereford em distintas condições reprodutivas criadas extensivamente. Ciência Rural, v. 35, p. 150-156, 2005. Available at: http://www.scielo.br/scielo.php?script=sci_arttext\&pid=S0103$84782005000100024 \& \operatorname{lng}=$ pt\&nrm=iso\&tlng=PT. Accessed on: Nov. 23, 2014. Doi: /10.1590/S010384782005000100024

PIMENTEL, M. A.; MORAES, J. C. F.; JAUME, C. M.; LEMES, J. S.; BRAUNER, C. C. Características da lactação de vacas Hereford criadas em um sistema de produção extensivo na região da Campanha do Rio Grande do Sul. Revista Brasileira de Zootecnia, v. 35, n. 1, p. 159-168, 2006. Available at: http://www.scielo.br/scielo.php?script=sci_arttext\&pid=S151635982006000100021\&lng=en\&nrm=iso\&tlng=PT. Accessed on Nov. 10, 2014. doi: /10.1590/S151635982006000100021 
RESTLE, J.; VAZ, R. Z.; ALVES FILHO, D. C.; BERNARDES, R. A. C.; PASCOAL, L. L.; SENNA, D. B.; POLLI, V. A. Desempenho de vacas Charolês e Nelore desterneiradas aos três ou sete meses. Revista Brasileira de Zootecnia, v. 30, n. 2, p. 499-507, 2001. Available at: http://www.scielo.br/scielo.php?script=sci_arttext\&pid=S151635982001000200029\&lng=en\&nrm=iso\&tlng=PT. Accessed on Dec. 17, 2014. doi: /10.1590/S151635982001000200029

RESTLE, J.; PACHECO, P. S.; PÁDUA, J. T.; ROCHA, M. G.; VAZ, R. Z.; EIFERT, E. C.; MOLETTA, J. L.; FREITAS, A. K. Eficiência biológica de vacas de dois grupos genéticos amamentando bezerros puros ou F1, mantidas em diferentes condições de alimentação. Revista Brasileira de Zootecnia, v. 33, n. 6, p. 18221832, 2004 (Suplemento 1). Available at: http://www.scielo.br/scielo.php?script=sci_arttext\&pid=S151635982004000700021\&lng=en\&nrm=iso\&tlng=PT. Accessed on: Nov. 18, 2014. doi: 10.1590/S151635982004000700021

RIBEIRO, E. L. A.; RESTLE, J.; ROCHA, M. A.; MIZUBUTI, I. Y.; SILVA, L. D. F. Eficiência produtiva em vacas primíparas das raças Aberdeen Angus e Charolês. Revista Brasileira de Zootecnia, v. 30, n. 1, p. 125132, 2001. Available at: http://www.scielo.br/scielo.php?script=sci_arttext\&pid=S151635982001000100019\&lng=en\&nrm=iso\&tlng=PT. Accessed on Nov. 21, 2014. doi: 10.1590/S151635982001000100019

ROSA, A. A. G. LOBATO, J. F. P.; VAZ, R. Z. Natural and improved pastures on the growth and reproductive performance of Hereford heifers. Revista Brasileira de Zootecnia, v. 41, n. 1, p. 203-211, 2012. Available at: http://www.scielo.br/scielo.php?script=sci_arttext\&pid=S1516-

35982012000100029\&lng=en\&nrm=iso\&tlng=em. Accessed on Dec. 21, 2014. doi: 10.1590/S151635982012000100029

ROVIRA, J. M. Manejo nutritivo de los rodeos de cria em pastoreo. Montivideo: Hemisfério Sur, 1996. 288 p.

VARGAS, C. A.; OLSON, T. A.; CHASE, C. C.; HAMMOND, A. C.; ELZO, M. A. Influence of frame size and body condition score on performance of Brahman cattle. Journal of Animal Science, v. 77, n. 12, p. 31403149, 1999. Available at: https://www.animalsciencepublications.org/publications/jas/pdfs/77/12/3140?searchresult=1. Accessed on: Nov. 29, 2014.

VAZ, R. Z.; LOBATO, J. F. P. Efeito da idade de desmame no desempenho reprodutivo de novilhas de corte expostas à reprodução aos 13/15 meses de idade. Revista Brasileira de Zootecnia, v. 39, n. 1, p. 142-150, 2010a. Available at: http://www.scielo.br/scielo.php?script=sci_arttext\&pid=S1516-

35982010000100019\&lng=en\&nrm=iso\&tlng=PT. Accessed on Nov. 23, 2014. doi: 10.1590/S151635982010000100019

VAZ, R. Z.; LOBATO, J. F. P. Effects of the weaning age of calves on somatic development and on reproductive performance of beef cows. Revista Brasileira de Zootecnia, v. 39, n. 5, p. 1058-1067, 2010 b. Available at: http://www.scielo.br/scielo.php?script=sci_arttext\&pid=S1516-

$35982010000500016 \& \operatorname{lng}=e n \& n r m=i s o \& t \operatorname{lng}=e m$. Accessed on Nov. 10, 2014. doi: 10.1590/S151635982010000500016.

VAZ, R. Z.; LOBATO, J. F. P.; RESTLE, J. Influence of weaning age on the reproductive efficiency of primiparous cows. Revista Brasileira de Zootecnia, v. 39, p. 299-307, 2010a. Available at:

http://www.scielo.br/scielo.php?script=sci_arttext\&pid=S1516-

35982010000200011\&lng=en\&nrm=iso\&tlng=em. Accessed on: Nov. 16, 2014. doi: 10.1590/S151635982010000200011 
VAZ, R. Z.; LOBATO, J. F. P.; RESTLE, J. Productivity and efficiency of cow herds submitted to two weaning ages. Revista Brasileira de Zootecnia, v. 39, p. 1849-1856, 2010b. Available at: http://www.scielo.br/scielo.php?script=sci_arttext\&pid=S151635982010000800030\&lng=en\&nrm=iso\&tlng=em. Accessed on Dec. 20, 2014. doi: 10.1590/S151635982010000800030

WETTEMANN, R. P.; LENTS, C. A.; CICCIOLI, N. H.; WHITE, F. J.; RUBIO, I. Nutritional - and suckling - mediated anovulation in beef cows. Journal of Animal Science, v. 81, n. 1, p. 48-59, 2003. Available at: https://www.animalsciencepublications.org/publications/jas/articles/81/2/0810376?highlight=\&search-result=1. Accessed on: Nov. 22, 2014. doi: 2003.8114_suppl_2E48x. 